\title{
Ionophoric action of trans-isohumulone on Lactobacillus brevis
}

\author{
W. J. SIMPSON* \\ BRF International, Nutfield, Surrey RHI $4 H Y, U K$ \\ (Received 21 September 1992; revised 24 January 1993; accepted 1 February 1993)
}

\begin{abstract}
Compounds (e.g. trans-isohumulone) derived from flowers of the hop plant (Humulus lupulus L.) protect beer from spoilage. Cells of Lactobacillus brevis IFO 3960 did not die when they were exposed to $40 \mu \mathrm{M}$-trans-isohumulone for up to $120 \mathrm{~h}$. At higher concentrations $(80,120 \mu \mathrm{M})$ death occurred after a lag period of about $30 \mathrm{~h}$. transIsohumulone dissipated the transmembrane $\mathrm{pH}$ gradient of non-growing cells and reduced their ability to accumulate $\mathrm{L}-\left[\mathrm{U}-{ }^{14} \mathrm{C}\right]$ leucine. The membrane potential was dissipated to a smaller extent. Addition of transisohumulone to cells that had accumulated $\mathrm{L}\left[\mathrm{U}-{ }^{14} \mathrm{C}\right]$ leucine, under conditions in which no synthesis of protein took place, caused slow leakage of radiolabelled leucine. trans-Isohumulone did not inhibit the activity of the protontranslocating membrane ATPase. Potentiometric experiments with resting cell suspensions suggested that transisohumulone acted as an ionophore of the mobile-carrier type, causing electroneutral exchange of $\mathrm{H}^{+}$for divalent cations such as $\mathrm{Mn}^{2+}$. A second monovalent cation (e.g. $\mathrm{K}^{+}$) was essential for protonophoric activity.
\end{abstract}

\section{Introduction}

Bitter compounds (cis- and trans-isohumulone and congeners) derived from the hop plant (Humulus lupulus L.) have antibacterial properties. They interfere with plasma membrane function in Bacillus subtilis (Teuber \& Schmalreck, 1973; Schmalreck et al., 1975) but the mechanism by which beer-spoilage bacteria (Lactobacillus spp., Pediococcus spp.) are inhibited has not been reported. This is relevant since these organisms employ substrate-level phosphorylation (a cytoplasmic process) to generate ATP (Harold, 1986). The undissociated forms of hop compounds and hop-derived compounds exert their antibacterial action on lactic acid bacteria. The ionized forms of such compounds have negligible activity. Divalent cations diminish the activity of transisohumulone; monovalent cations stimulate it (Simpson \& Smith, 1992).

Here, the effects of trans-isohumulone (Fig. 1) on cells of Lactobacillus brevis IFO 3960 are reported and its ionophoric properties demonstrated. A preliminary report of some of the results has been published previously (Simpson \& Hammond, 1991).

\section{Methods}

Materials. Chemicals were from Sigma, BDH or Amersham International. trans-Isohumulone was prepared and characterized as

\footnotetext{
* Tel. (0737) 822272; fax (0737) 822747.
}

Abbreviations: CCCP, carbonyl cyanide $m$-chlorophenylhydrazone; NaDMG, sodium 3,3'-dimethylglutarate. described previously (Simpson \& Smith, 1992). Sodium 3,3'-dimethylglutarate buffer (NaDMG, $\mathrm{pH} \mathrm{5.2)}$ was prepared by titrating $0.1 \mathrm{M}$ $\mathrm{NaOH}$ with solid 3,3'-dimethylglutaric acid. The medium of de Man et al. (1960) (MRS) was modified by omission of Tween 80 (Simpson \& Smith, 1992) and adjusted to $\mathrm{pH} 5 \cdot 2$ with concentrated $\mathrm{HCl}$. L. brevis IFO 3960 from the Institute of Fermentation (Osaka, Japan) was subcultured at three monthly intervals on MRS agar.

Chemical analyses. Concentrations of $\mathrm{SO}_{4}^{2-}, \mathrm{PO}_{4}^{3-}, \mathrm{K}^{+}, \mathrm{Na}^{+}, \mathrm{NH}_{4}^{+}$, $\mathrm{Mg}^{2+}$ and $\mathrm{Ca}^{2+}$ were estimated by ion-exchange chromatography (Simpson, 1991). Cellular ATP was extracted with TCA (Lundin, 1984) or detergents (Simpson \& Hammond, 1989) and analysed with the firefly luciferase assay (Simpson \& Hammond, 1989).

Effect of trans-isohumulone on exponentially growing cells. Stationaryphase organisms $(1.5 \mathrm{ml})$, grown for $3 \mathrm{~d}$ at $25^{\circ} \mathrm{C}$ in modified MRS, were transferred to fresh medium $(150 \mathrm{ml})$ and incubated at $25^{\circ} \mathrm{C}$ with shaking. When the number of organisms reached approximately $4 \times 10^{7} \mathrm{ml}^{-1}\left(\mathrm{OD}_{560}=0.5\right)$ trans-isohumulone $(0-120 \mu \mathrm{M})$ was added as a methanolic solution (controls received methanol). Growth was monitored by measurement of $\mathrm{OD}_{560}$, viable cell count (MRS agar) and cellular ATP content. Cell morphology was examined by electron microscopy $n$ nd light microscopy. Leakage of ATP was assessed by analysis of membrane-filtered growth media.

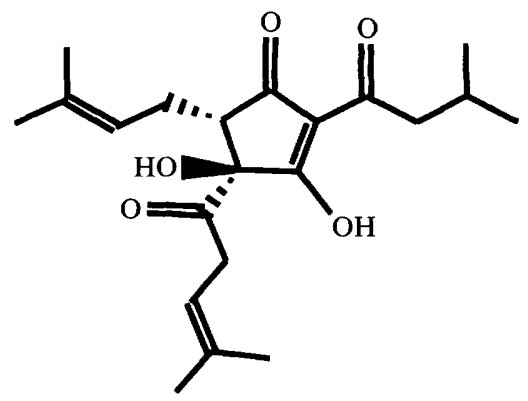

Fig. 1. Chemical structure of trans-isohumulone. 
Effect of trans-isohumulone on non-growing cells. L. brevis IFO 3960 was grown in modified MRS $\left(25^{\circ} \mathrm{C}, 16.5 \mathrm{~h}\right.$ with agitation). The exponentially-growing organisms $\left(\mathrm{OD}_{560}=1.0\right)$ were centrifuged $\left(3000 \mathrm{~g}, 4^{\circ} \mathrm{C} ; 10 \mathrm{~min}\right)$ and washed twice with NaDMG buffer. They were then resuspended in buffer with glucose $\left(10 \mathrm{~g} \mathrm{l}^{-1}\right)$ and transisohumulone $(0-400 \mu \mathrm{M})$. The cell suspensions (approximately $5 \cdot 6 \times 10^{7} \mathrm{ml}^{-1}$ ) were shaken at $25^{\circ} \mathrm{C}$ for $60 \mathrm{~min}$, then analysed for (i) viable cell count on MRS agar, (ii) intracellular ATP content, (iii) cell morphology, and (iv) $\mathrm{OD}_{560}$. Membrane-filtered supernatant fluids were analysed for intracellular materials [ATP, anions, cations, UV $(260 \mathrm{~nm})$-absorbing materials] to check for plasma membrane damage.

Measurement of intracellular $\mathrm{pH}$ and membrane potential. Intracellular $\mathrm{pH}\left(\mathrm{pH}_{\mathrm{int}}\right)$ and membrane potential $(\Delta \psi)$ were estimated from the transmembrane distribution of $\left[{ }^{14} \mathrm{C}\right]$ salicylic acid or $\left[{ }^{3} \mathrm{H}\right]$ tetraphenylphosphonium ions $\left(\mathrm{TPP}^{+}\right)$respectively (Ten Brink et al., 1985). Cells grown for $3 \mathrm{~d}$ in modified MRS were chilled and harvested by centrifugation $\left(3000 \mathrm{~g}, 10 \mathrm{~min}, 4^{\circ} \mathrm{C}\right)$. After two washes in cold buffer (NaDMG, containing $10 \mathrm{~g}$ glucose $1^{-1}$ ) they were resuspended in fresh buffer at $25^{\circ} \mathrm{C}$ to a cell density of $8 \times 10^{8} \mathrm{ml}^{-1}$. trans-Isohumulone $(400 \mu \mathrm{M})$ or a combination of carbonyl cyanide $m$-chlorophenylhydrazone (CCCP, $30 \mu \mathrm{M})$ and valinomycin $(0.45 \mu \mathrm{M})$ were added as methanolic solutions (controls received methanol). The suspensions were then incubated at $25^{\circ} \mathrm{C}$ for $60 \mathrm{~min}$ before measuring $\mathrm{pH}_{\mathrm{int}}$ and $\Delta \psi$.

Effect of trans-isohumulone on uptake and efflux of $L_{-}\left[U_{-}{ }^{14} C\right]$ leucine by L. brevis IFO 3960. Cells grown for $3 \mathrm{~d}$ at $25^{\circ} \mathrm{C}$ in modified MRS were chilled to $4{ }^{\circ} \mathrm{C}$, harvested by centrifugation $\left(3000 \mathrm{~g}, 4^{\circ} \mathrm{C} ; 10 \mathrm{~min}\right)$ then washed twice with cold buffer (NaDMG containing $10 \mathrm{~g}$ glucose $\left.1^{-1}\right)$. After resuspension in fresh buffer $\left(8 \times 10^{8} \mathrm{ml}^{-1}\right)$ they were incubated for $60 \mathrm{~min}$ at $25^{\circ} \mathrm{C}$. The resuspension buffer contained chloramphenicol $\left(50 \mathrm{mg} \mathrm{l}^{-1}\right)$ to prevent incorporation of $\mathrm{L}-\left[\mathrm{U}-{ }^{14} \mathrm{C}\right]-$ leucine into protein. $\mathrm{L}-\left[\mathrm{U}-{ }^{14} \mathrm{C}\right]$ Leucine $\left(1.85 \times 10^{4} \mathrm{~Bq}, 1.62 \mu \mathrm{M}\right)$ was added to portions of the suspension and, at intervals during the incubation $\left(25^{\circ} \mathrm{C}\right)$, the cells were separated from the supernatant by filtration through silicone oil (Ten Brink et al., 1985). The radioactivity associated with each cell pellet was then measured.

The ability of $L$. brevis IFO 3960 to retain pre-loaded L-[U- $\left.{ }^{14} \mathrm{C}\right]-$ leucine in the presence of CCCP, valinomycin and transisohumulone was studied. Cells were loaded with $\mathrm{L}-\left[\mathrm{U}-{ }^{14} \mathrm{C}\right]$ leucine for $20 \mathrm{~min}$. Immediately before the end of the $20 \mathrm{~min}$ incubation, the suspension was divided into portions $(1.2 \mathrm{ml}$ each). The following additions ( $6 \mu \mathrm{l}$ each) were made to each tube: (i) methanol, (ii) transisohumulone $(80 \mathrm{mM})$, (iii) CCCP $(60 \mathrm{mM})$, and (iv) valinomycin $(90 \mu \mathrm{M})$ and CCCP $(6 \mathrm{mM})$. Samples $(200 \mu \mathrm{l})$ were removed from each tube at 5, 10, 20 and $30 \mathrm{~min}$, and the radioactivity in the cell pellet was measured.

Effect of trans-isohumulone on activity of the membrane-bound ATPase. The proton-translocating ATPase of L. brevis IFO 3960 was isolated and its activity assessed (Bender et al., 1986). The reaction mixture contained NaDMG buffer ( $16 \mathrm{ml}, 50 \mathrm{~mm}, \mathrm{pH} 4 \cdot 5), \mathrm{MgSO}_{4}$ $(10 \mathrm{~mm})$, glycerol $(10 \%, \mathrm{v} / \mathrm{v})$ and $54 \mathrm{mg}$ membrane protein $1^{-1}$. It was warmed to $30^{\circ} \mathrm{C}$ and divided into two portions. Methanol $(40 \mu \mathrm{l})$ was added to one portion and trans-isohumulone $(60 \mu \mathrm{M})$ to the other. The reaction was initiated $10 \mathrm{~min}$ later by addition of ATP $(6 \mathrm{mM})$. Samples $(1 \mathrm{ml})$ were withdrawn from the mixture immediately and at $3 \mathrm{~min}$ intervals up to $30 \mathrm{~min}$. The phosphate content of each sample was then determined (Serrano, 1978). Membrane protein content was measured as described by Spector (1978) using bovine- $\gamma$-globulin as standard.

Effect of trans-isohumulone and ionophores on the passive proton permeability (Harold \& Baarda, 1968). Cells of L. brevis IFO 3960 were grown in modified MRS for $16.5 \mathrm{~h}$ at $25^{\circ} \mathrm{C}$ with shaking, harvested by centrifugation $\left(3000 \mathrm{~g}, 4^{\circ} \mathrm{C} ; 30 \mathrm{~min}\right)$, washed twice with cold deionized water and stored at $4{ }^{\circ} \mathrm{C}$. They were resuspended to a concentration of about $1 \times 10^{9}$ organisms $\mathrm{ml}^{-1}$ in an unbuffered medium containing $\mathrm{KCl}$
$(150 \mathrm{mM})$ and $\mathrm{MgCl}_{2}(2 \mathrm{mM})$ at a range of temperatures $\left(0-24^{\circ} \mathrm{C}\right)$. Cells were transferred to a vessel ( $25 \mathrm{ml}$ capacity) and sparged with $\mathrm{O}_{2}$-free $\mathrm{N}_{2}$ gas. The suspension $\mathrm{pH}$ was monitored with a $\mathrm{pH}$ meter and adjusted to 6.5 with $\mathrm{NaOH}$. A pH gradient was imposed by addition of $\mathrm{HCl}(100 \mu \mathrm{M})$. Antibacterial agents $(\mathrm{CCCP}, 15 \mu \mathrm{M}$; valinomycin, $0.45 \mu \mathrm{M}$ or trans-isohumulone, $100 \mu \mathrm{M}$ ) or methanol alone were then added. Further additions were made as appropriate. The methanol concentration did not exceed $0.2 \%$ in any experiment. Occasionally deionized water was used as the suspending medium and $\mathrm{pH}$ was not adjusted. In some experiments $\mathrm{KCl}, \mathrm{NaCl}, \mathrm{CaCl}_{2}, \mathrm{MgCl}_{2}$ or $\mathrm{MnCl}_{2}$ were added to the suspensions. In others the medium was analysed for $\mathrm{Na}^{+}, \mathrm{K}^{+}, \mathrm{NH}_{4}^{+}, \mathrm{Ca}^{2+}$ and $\mathrm{Mg}^{2+}$, before and after treatment with transisohumulone $(100 \mu \mathrm{M})$.

Interaction between trans-isohumulone and $\mathrm{Mn}^{2+}$. The interaction between trans-isohumulone and $\mathrm{Mn}^{2+}$ in methanol was studied by UV spectroscopy (Pfeiffer et al., 1974).

\section{Results and Discussion}

\section{Effect of trans-isohumulone on growing organisms}

There was a concentration-dependent reduction in growth rate in the presence of trans-isohumulone. The growth of cells exposed to $40 \mu \mathrm{M}$-trans-isohumulone was arrested immediately after it was added to the cell suspension. Growth resumed after a lag period of $7 \mathrm{~h}$ if the organisms were resuspended in fresh growth medium. The lag phase of untreated organisms was $1 \mathrm{~h}$. No death occurred when the cells were exposed to $40 \mu \mathrm{M}$-transisohumulone for up to $120 \mathrm{~h}$. At higher concentrations $(80,120 \mu \mathrm{M})$ death occurred after a lag of about $30 \mathrm{~h}$. The rates of death induced by 80 and $120 \mu \mathrm{M}$-transisohumulone were similar. Some cell lysis occurred after about $60 \mathrm{~h}$ contact with 80 and $120 \mu \mathrm{M}$-transisohumulone at $25^{\circ} \mathrm{C}$, as shown by a reduction in $\mathrm{OD}_{560}$, ATP leakage and microscopy. In addition, after $40 \mathrm{~h}$ exposure to $80 \mu \mathrm{M}$-trans-isohumulone, the length of treated cells was $25 \cdot 5 \pm 6 \cdot 8 \mu \mathrm{m}$ (mean $\pm \mathrm{SD}, n=100$ ), whereas that of the untreated organisms was $40 \cdot 3 \pm 9 \cdot 4 \mu \mathrm{m}(n=100)$ as estimated by electron microscopy. The organisms did not aggregate in the presence of trans-isohumulone.

In the early stages of contact with $40 \mu \mathrm{M}$-transisohumulone there was a reduction, followed by a threefold stimulation, in ATP content (Fig. 2). Higher concentrations of trans-isohumulone $(80,120 \mu \mathrm{M})$ reduced the ATP content of cells. No ATP leaked from treated organisms when trans-isohumulone was added, indicating that the integrity of the cell membrane was maintained. At concentrations of trans-isohumulone that caused a reduction in viable count, the reduction in ATP content was small.

\section{Effect of trans-isohumulone on non-growing organisms}

The viability of $L$. brevis IFO 3960 was not affected by $60 \mathrm{~min}$ exposure to $400 \mu \mathrm{M}$-trans-isohumulone, equivalent to $10 \times$ the MIC under these conditions. However, 


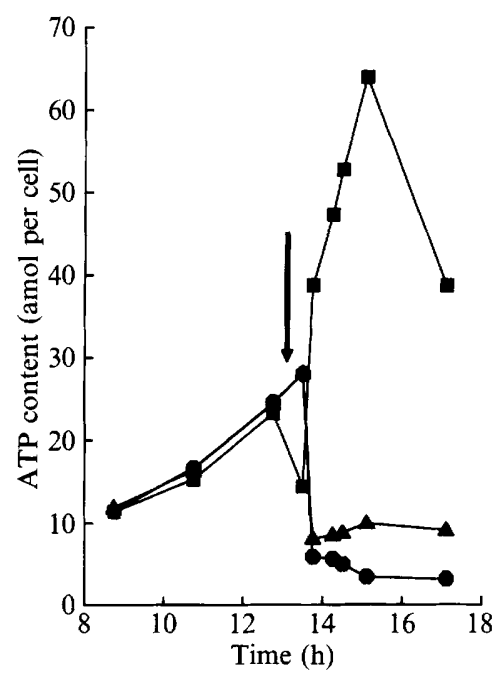

Fig. 2. Effect of trans-isohumulone on cellular ATP content of growing organisms. Immediately before addition (arrow) of $40(\boldsymbol{G}), 80(\boldsymbol{A})$ or 120 (O) $\mu \mathrm{M}$-trans-isohumulone (final concentration), the exponentially growing culture contained approximately $3 \times 10^{7}$ organisms $\mathrm{ml}^{-1}$, each of which contained $2 \times 10^{-17} \mathrm{~mol}$ ATP. The data shown represent the mean of duplicate determinations. The error did not exceed $10 \%$ of the mean in any case.

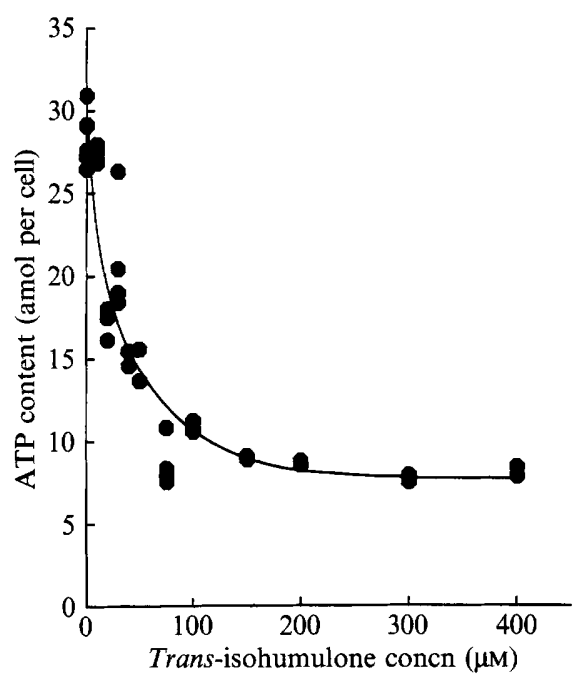

Fig. 3. Effect of trans-isohumulone on the intracellular ATP content of non-growing cells of $L$. brevis IFO 3960 . A standardized suspension of organisms (approximately $5.6 \times 10^{7} \mathrm{ml}^{-1}$ ) was prepared in $\mathrm{NaDMG}$ buffer containing glucose $\left(10 \mathrm{~g} \mathrm{l}^{-1}\right)$, exposed to different concentrations of trans-isohumulone for $60 \mathrm{~min}$ and their ATP content then assayed.

the ATP content of the cells was reduced (Fig. 3). Microscopy, $\mathrm{OD}_{560}$ and measurement of their ability to retain a pool of ATP and UV absorbing material indicated that the structural integrity of the plasma membranes was not impaired.

Uptake of $\mathrm{L}-\left[\mathrm{U}-{ }^{14} \mathrm{C}\right]$ leucine by $L$. brevis IFO 3960 was inhibited by the combined action of CCCP and valinomycin and, to a lesser extent, by CCCP alone.
Leucine uptake in this organism was probably mediated by a proton motive force $(\Delta p)$-dependent carrier that was energized by both $\Delta \mathrm{pH}$ and $\Delta \psi$ components. transIsohumulone also inhibited uptake of $\mathrm{L}-\left[\mathrm{U}-{ }^{14} \mathrm{C}\right]$ leucine (Fig. 4a). Furthermore, application of trans-isohumulone (or CCCP and valinomycin) to cells that were pre-loaded with $\mathrm{L}-\left[\mathrm{U}-{ }^{14} \mathrm{C}\right]$ leucine caused them to slowly lose the label (Fig. 4b). A concentration of transisohumulone of $400 \mu \mathrm{M}$ was equivalent approximately to the MIC for growth at this cell concentration (as estimated from the effect of trans-isohumulone on ATP content).

trans-Isohumulone at $400 \mu \mathrm{M}$ dissipated the transmembrane $\mathrm{pH}$ gradient $(\Delta \mathrm{pH})$ of $L$. brevis IFO 3960 . Control cells incubated for $60 \mathrm{~min}$ in NaDMG containing glucose had a $\Delta \mathrm{pH}$ of $0.52 \pm 0.002$ (mean \pm sEM; $n=3$ ). Those treated with $400 \mu \mathrm{M}$ trans-isohumulone had a $\Delta \mathrm{pH}$ of $0.09 \pm 0.09(n=3)$. The effects on $\Delta \psi$ were less pronounced: the values of $\Delta \psi$ were $-71 \cdot 5 \pm 3 \cdot 1 \mathrm{mV}$ and $-42 \cdot 7 \pm 9 \cdot 9 \mathrm{mV}(n=3)$, obtained for control organisms and those treated with trans-isohumulone, respectively.

\section{Ionophoric activity of trans-isohumulone.}

In lactic acid bacteria, $\Delta \mathrm{pH}$ is an important component of $\Delta p$, providing a mechanism by which generation of energy (ATP) and its utilization for nutrient transport can be coupled (Kashket, 1987). In addition, the intracellular $\mathrm{pH}$ influences nutrient transport and metabolic processes indirectly (Poolman et al., 1987). The ability of an antibacterial agent to dissipate $\Delta \mathrm{pH}$ can result from any of several mechanisms: (i) it may inhibit the activity of the proton-translocating ATPase, (ii) it may inhibit energy generation causing a reduction in ATPase activity due to a lack of ATP, or (iii) it may decrease the natural impermeability of the cell membrane to $\mathrm{H}^{+}$or other cations. This may result from significant physical disruption of the membrane or from effects on its permeability to specific ions. The activity of the membrane-bound ATPase of $L$. brevis IFO 3960 was not affected by $60 \mu \mathrm{M}$-trans-isohumulone at $\mathrm{pH} 4.5$. An ATPase activity of $266 \mathrm{nmol}$ phosphate (mg protein) ${ }^{-1}$ $\min ^{-1}$ was obtained in the presence and absence of transisohumulone. Also, ATP limitation was not responsible for growth inhibition since the cellular concentration of ATP increased when growth was inhibited.

Ionophores transport ions across membranes (Harold, 1986). True ionophores move freely through membranes, whereas quasi-ionophores form a stationary pore. The activity of true ionophores is temperature-dependent, unlike that of quasi-ionophores. The permeability of resting cell suspensions of $L$. brevis IFO 3960 to protons can be expressed in terms of their equilibration times 


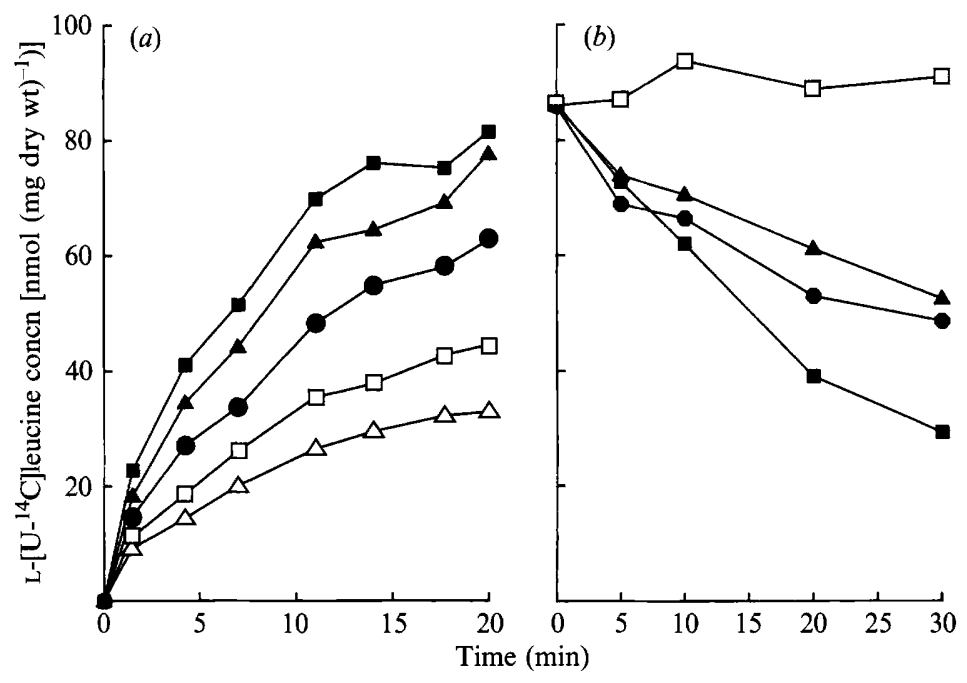

Fig. 4. Effect of trans-isohumulone on uptake and efflux of L-[U- $\left.{ }^{14} \mathrm{C}\right]$ leucine by $L$. brevis IFO 3960. (a) trans-Isohumulone [0 ( $\left.\boldsymbol{\square}\right), 40$ $(\triangle), 80(\bullet), 200(\square)$ and $400(\triangle) \mu \mathrm{M}]$ was added to organisms (approx. $8 \times 10^{8} \mathrm{ml}^{-1}$ ) suspended in NaDMG buffer (containing glucose). After $5 \mathrm{~min}, \mathrm{~L}-\left[\mathrm{U}-{ }^{14} \mathrm{C}\right]$ leucine was added and its uptake by the cells monitored. Chloramphenicol was present to prevent incorporation of $\mathrm{L}-\left[\mathrm{U}-{ }^{14} \mathrm{C}\right]$ leucine into protein. (b) Organisms which had been pre-loaded with $\mathrm{L}-\left[\mathrm{U}-{ }^{14} \mathrm{C}\right]$ leucine for 20 min were exposed to $400 \mu \mathrm{M}-$

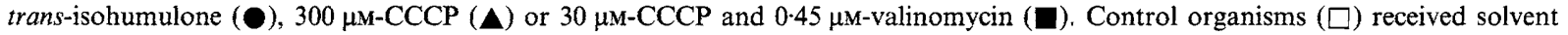
only. The efflux of radiolabel from the cells was then monitored. In both experiments each point represents the mean of four determinations. The error in each case was no greater than $5 \%$ of the mean.

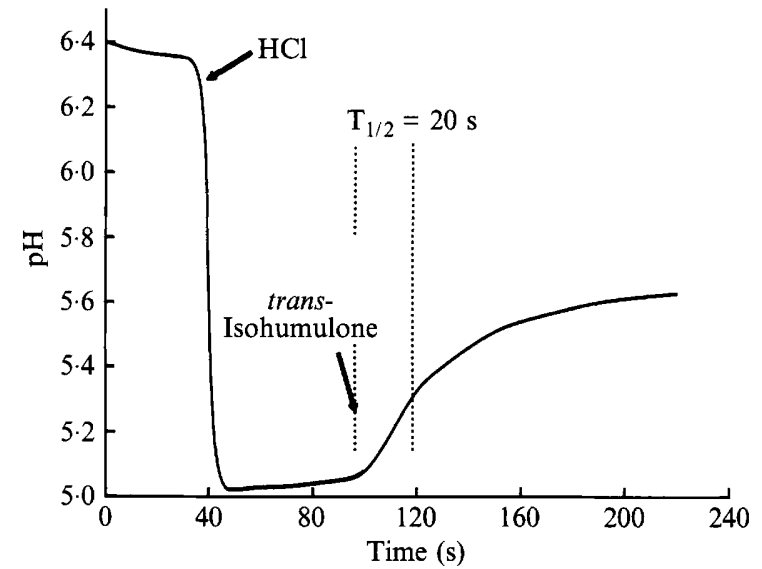

Fig. 5. trans-Isohumulone causes an influx of protons into $L$. brevis IFO 3960. Organisms (approximately $1 \times 10^{9} \mathrm{ml}^{-1}$ ) were suspended in $\mathrm{KCl}(150 \mathrm{~mm})$, and $\mathrm{MgCl}_{2}$ (2 mM). Net proton movements were monitored by changes in extracellular $\mathrm{pH}$. $\mathrm{HCl}(100 \mu \mathrm{M})$ and transisohumulone $(100 \mu \mathrm{M})$ were added at the stages indicated.

( $T_{1 / 2}$, the time required to dissipate one-half of the difference between the starting and equilibrium $\mathrm{pH}$ values). Control suspensions had a $T_{1 / 2}$ of $2 \cdot 8 \mathrm{~min}$. CCCP or valinomycin only reduced $T_{1 / 2}$ slightly ( 2.5 and $2.3 \mathrm{~min}$ respectively). This was because the ability of CCCP to catalyse transmembrane proton movements was soon limited by the development of a membrane potential. When both CCCP and valinomycin were present, CCCPinduced proton movements were balanced by valinomycin-induced $\mathrm{K}^{+}$movements and the resulting $\mathrm{H}^{+}$ingress was rapid $\left(\mathrm{T}_{1 / 2}=0.3 \mathrm{~min}\right)$. transIsohumulone caused an increase in proton permeability $\left(\mathrm{T}_{1 / 2}=0.3 \mathrm{~min}\right.$; Fig. 5), suggesting that it acts as an ionophore. The process was apparently electroneutral since the proton movements were not limited by development of a membrane potential. Also, relief of electrical constraints by valinomycin did not affect the rate of proton movements.

The direction of proton ingress could be reversed by addition of $0.8 \mathrm{~mm}-\mathrm{Mn}^{2+}$ to the trans-isohumulonetreated cell suspension. This effect was not apparent when monovalent cations $\left(\mathrm{Na}^{+}, \mathrm{K}^{+}\right)$or other divalent cations $\left(\mathrm{Ca}^{2+}, \mathrm{Mg}^{2+}\right)$ were added instead of $\mathrm{Mn}^{2+}$. Analysis of extracellular fluids by ion-exchange chromatography showed that leakage of $\mathrm{Na}^{+}, \mathrm{NH}_{4}^{+}, \mathrm{Ca}^{2+}$ and $\mathrm{Mg}^{2+}$ did not occur (leakage of $\mathrm{K}^{+}$could not be tested for since it was present in the suspending medium). The high concentration of manganese in lactic acid bacteria such as $L$. brevis (typically $30 \mathrm{~mm}$; Archibald \& Fridovich, 1981) may favour its participation in the ionophoric action of trans-isohumulone.

At $25^{\circ} \mathrm{C}$, trans-isohumulone only displayed protonophoric activity when a second monovalent cation $\left(\mathrm{K}^{+}\right.$or $\mathrm{Na}^{+}$) was present in the suspending medium. It was inactive when the cells were suspended in water $\left(\mathrm{T}_{1 / 2}=2.8 \mathrm{~min}\right)$. The ability of trans-isohumulone to interact with the plasma membrane may be enhanced by monovalent cations. It may be relevant that, in aqueous 
solution, trans-isohumulone is unable to chelate $\mathrm{K}^{+}$ unless divalent or trivalent cations are present (W. J. Simpson \& P. S. Hughes, unpublished data).

The effects of trans-isohumulone were dependent on temperature. With $100 \mu \mathrm{M}$-trans-isohumulone, $\mathrm{T}_{1 / 2}$ values of $30,5 \cdot 6,2 \cdot 0$ and $0.3 \mathrm{~min}$ were obtained at $0,5,10$ and $20{ }^{\circ} \mathrm{C}$, respectively. Similar results were obtained regardless of whether trans-isohumulone was added before or after the temperature shift.

The ionophoric properties of trans-isohumulone clearly depend on its ability to complex metal ions. This property has been known for some time (Hudson \& Rudin, 1959) but the interaction of trans-isohumulone with $\mathrm{Mn}^{2+}$ had not been demonstrated. Spectroscopic experiments showed that, in methanol, transisohumulone binds to $\mathrm{Mn}^{2+}\left(K_{\mathrm{d}}<10^{5}\right)$. Other experiments (P. S. Hughes \& W. J. Simpson, unpublished data) have shown that its affinity for other physiologically significant divalent cations (e.g. $\mathrm{Mg}^{2+}$, $\mathrm{Ca}^{2+}$ ) is less than that for $\mathrm{Mn}^{2+}$.

These results imply that trans-isohumulone acts as a mobile-carrier of ions. Thus, at temperatures above the 'melting point' of the membrane lipids, it traps protons at one membrane surface and exchanges them for $\mathrm{Mn}^{2+}$ (or other divalent cations) at the other. The stoichiometry of the process is unknown. At lower temperatures, the mobility of trans-isohumulone in the cell membrane is reduced, thus restricting ionophoric activity. Experiments using liposomes, or other model membranes, will be necessary to confirm the ionophoric properties of trans-isohumulone.

I thank Jacqui Fernandez for technical assistance, N. L. Davies for electron microscopy, A. R. W. Smith, J. R. M. Hammond and C. W. Bamforth for critical discussion, and the Director General of BRF International for permission to publish.

\section{References}

ArChibald, F. S. \& Fridovich, I. (1981). Manganese and defenses against oxygen toxicity in Lactobacillus plantarum. Journal of Bacteriology 145, 442-451.

Bender, G. R., Sutton, S. V. W. \& Marquis, R. E. (1986). Acid tolerance, proton permeabilities, and membrane ATPases of oral streptococci. Infection and Immunity 53, 331-338.
De Man, J. C., Rogosa, M. \& Sharpe, M. E. (1960). A medium for cultivation of lactobacilli. Journal of Applied Bacteriology 23 130-135.

Harold, F. M. (1986). The Vital Force: A Study of Bioenergetics. New York: W. H. Freeman.

HAROLD, F. M. \& BAarda, J. R. (1968). Inhibition of membrane transport in Streptococcus faecalis by uncouplers of oxidative phosphorylation and its relationship to proton conduction. Journal of Bacteriology 96, 2025-2034.

Hudson, J. R. \& Rudin, A. D. (1959). Metal derivatives of isohumulone. Journal of the Institute of Brewing 65, 414 418 .

KASHKET, E. R. (1987). Bioenergetics of lactic acid bacteria: cytoplasmic $\mathrm{pH}$ and osmotolerance. FEMS Microbiology Reviews 46, 233-244.

LuNDIN, A. (1984). Extraction and automatic luminometric assay of ATP, ADP and AMP. In Analytical Applications of Bioluminescence and Chemiluminescence, pp. 491-501. Edited by L. E. Kricka, P. E. Stanley, G. H. G. Thorpe \& T. P. Whitehead. London: Academic Press.

Pfeiffer, D. R., ReED, P. W. \& LaRdy, H. A. (1974). Ultraviolet and fluorescent spectral properties of the divalent cation ionophore A23187 and its metal ion complexes. Biochemistry 13, 4007-4014.

Poolman, B., Driessen, A. J. M. \& Konings, W. N. (1987). Regulation of solute transport in streptococci by external and internal $\mathrm{pH}$ values. Microbiological Reviews 51, 498-508.

Schmalreck, A. F., Teuber, M., Reininger, W. \& Hartl, A. (1975). Structural features determining the antibiotic potencies of natural and synthetic hop bitter resins, their precursors and derivatives. Canadian Journal of Microbiology 21, 205-212.

Serrano, R. (1978). Characterisation of the plasma membrane ATPase of Saccharomyces cerevisiae. Molecular and Cellular Biochemistry 22. $51-63$.

Simpson, W. J. (1991). Molecular Structure and Antibacterial Function of Hop Resin Materials. PhD Thesis, Council for National Academic Awards, UK.

Simpson, W. J. \& Hammond, J. R. M. (1989). Cold ATP extractants compatible with constant light signal firefly luciferase reagents. In ATP Luminescence: Rapid Methods in Microbiology. Society for Applied Bacteriology Technical Series, vol. 26, pp. 45-52. Edited by P. E. Stanley, B. J. McCarthy \& R. Smither. Oxford: Blackwell Scientific Publications.

Simpson, W. J. \& HAMmOND, J. R. M. (1991). Antibacterial action of hop resin materials. In European Brewery Convention, Proceedings of the 23rd Congress, Lisbon, pp. 185-192. London: IRL Press.

Simpson, W. J. \& SMITH, A. R. W. (1992). Factors affecting antibacterial activity of hop compounds and their derivatives. Journal of Applied Bacteriology 72, 327-334.

SPECTOR, T. (1978). Refinement of the Coomassie blue method of protein quantification. Analytical Biochemistry 86, 142-146.

Ten Brink, B., Otto, R., Hansen, U.-P. \& Konings, W. N. (1985). Energy recycling by lactate efflux in growing and nongrowing cells of Streptococcus lactis. Journal of Bacteriology 162, 383-390.

Teuber, M. \& SCHMAlreCK, A. F. (1973). Membrane leakage in Bacillus subtilis 168 induced by the hop constituents lupulone, humulone, isohumulone and humulinic acid. Archives of Microbiology 94, 159-171. 